\title{
Norois
}

Environnement, aménagement, société

$232 \mid 2014$

Modes de vie, modes d'habiter des aînés entre inclusion et exclusion

\section{Philippe Subra, Géopolitique de l'aménagement du territoire}

\section{Jean Renard}

\section{(2) OpenEdition Journals}

Édition électronique

URL : http://journals.openedition.org/norois/5206

DOI : $10.4000 /$ norois.5206

ISSN : $1760-8546$

Éditeur

Presses universitaires de Rennes

Édition imprimée

Date de publication : 30 octobre 2014

Pagination : 93

ISBN : 978-2-7535-3974-7

ISSN : 0029-182X

Référence électronique

Jean Renard, « Philippe Subra, Géopolitique de l'aménagement du territoire », Norois [En ligne], 232 |

2014, mis en ligne le 30 octobre 2014, consulté le 30 novembre 2020. URL : http://

journals.openedition.org/norois/5206 ; DOI : https://doi.org/10.4000/norois.5206 
Philippe Subra, Géopolitique de l'aménagement du territoire, 2014, Deuxième édition, Paris, A. Colin, 345 p. $25 €$

L'ouvrage de P. Subra est une excellente mise à jour de la première édition de 2007, et non une simple reprise. Les preuves en sont les développements consacrés au projet très controversé d'aéroport de Notre-Dame-des-Landes, la question des permis d'exploration du gaz de schiste, ou encore le problème de la fermeture de la centrale de Fessenheim.

Alors que la question des conflits est au programme des concours cette nouvelle édition vient à son heure.

L'ouvrage est organisé en huit chapitres avec une classification des conflits en fonction de leur nature. Sont successivement évoqués les projets autoroutiers, les projets énergétiques, les implantations industrielles, les grands projets dits structurants d'aéroports ou de lignes nouvelles de TGV. Par l'examen d'études de cas l'auteur montre les enjeux, le rôle des différents acteurs, les rapports de force, les évolutions liées aux mobilisations citoyennes, les concurrences et rivalités entre les territoires. Cartes et croquis illustrent les analyses.

Un dernier chapitre est consacré à la question controversée de la concertation organisée sur les projets d'équipements par les services de l'État. Les résultats mitigés et les limites de cette concertation sont évoqués, exemples à l'appui.

Tout aménagement dérange des situations établies, provoque des rejets d'une partie de la société locale, les choix sont toujours discutés et discutables. L'approche purement technicienne est désormais remise en cause par les organisations de défense de l'environnement et par la société civile qui subit l'impact des aménagements, cette dernière de mieux en mieux informée et apte à argumenter.

Le grand virage des années 1980 et le passage d'un aménagement du territoire triomphant du temps des Trente Glorieuses, aux mains des seuls techniciens et des élites imposant leur point de vue pour le bien commun et l'intérêt général, est examiné et discuté. L'auteur démontre que désormais la multiplication des conflits sur les territoires tient à de multiples

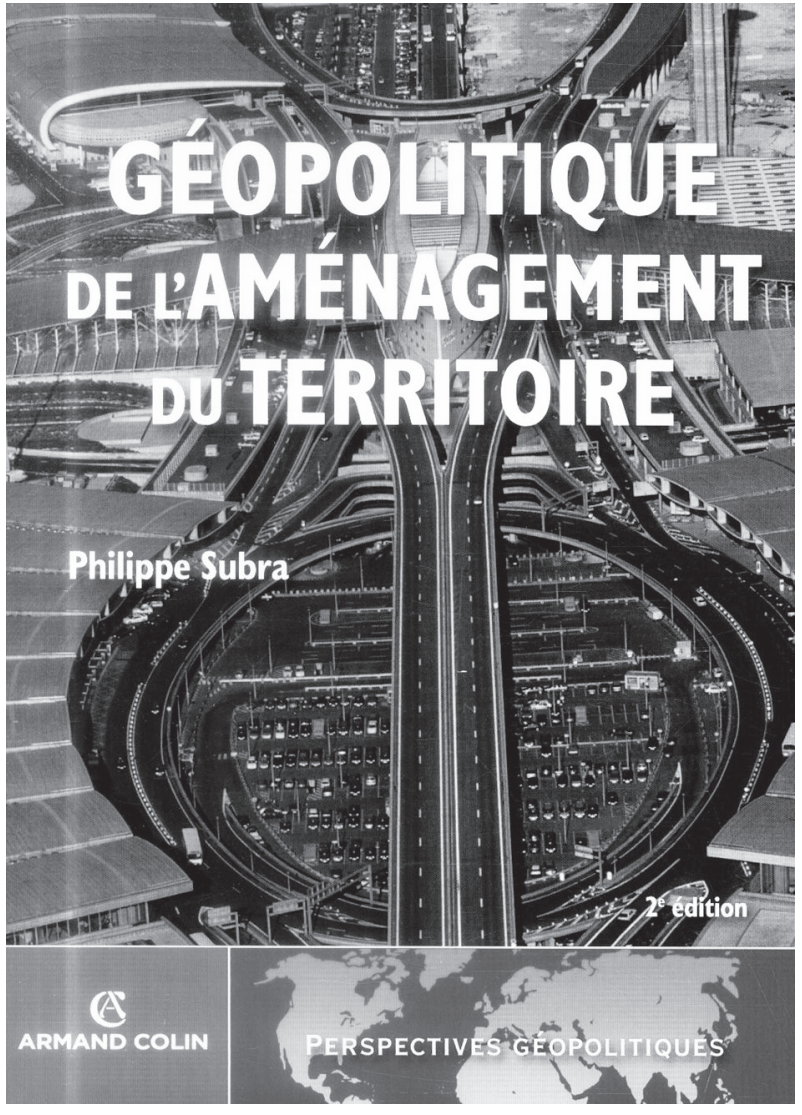

raisons, la plus importante est peut-être les changements dans la composition sociale des populations impactées, et la prise en compte des réalités écologiques dans notre société en crise.

Si l'essentiel des développements est consacré à la France métropolitaine, le chapitre 6 intitulé «Ailleurs en Europe et dans le monde » (p. 209250) examine en Allemagne, Italie, États-Unis, Turquie, Chine ou en Amérique latine des projets contestés d'aménagement qui ont été largement médiatisés depuis quelques années.

Bien écrit, très documenté, non partisan, avec des exemples nombreux et illustrés, cet ouvrage est à recommander.

Jean Renard 